\title{
Rapid Activity-Dependent Delivery of the Neurotrophic Protein CPG15 to the Axon Surface of Neurons in Intact Xenopus Tadpoles
}

\author{
Isabel Cantallops, Hollis T. Cline \\ Cold Spring Harbor Laboratory, Cold Spring Harbor, New York 11724
}

Received 25 February 2007; accepted 12 April 2007

\begin{abstract}
CPG15 (aka neuritin) is an activityinduced GPI-anchored axonal protein that promotes dendritic and axonal growth, and accelerates synaptic maturation in vivo. Here we show that CPG15 is distributed inside axons and on the axon surface. CPG15 is trafficked to and from the axonal surface by membrane depolarization. To assess CPG15 trafficking in vivo, we expressed an ecliptic pHluorin (EP)-CPG15 fusion protein in optic tectal explants and in retinal ganglion cells of intact Xenopus tadpoles. Depolarization by $\mathrm{KCl}$ increased EP-CPG15 fluorescence on axons. Intraocular kainic acid (KA) injection rapidly increased
\end{abstract}

cell-surface EP-CPG15 in retinotectal axons, but coinjection of TTX and KA did not. Consistent with this, we find that intracellular CPG15 is localized to vesicles and endosomes in presynaptic terminals and colocalizes with synaptic vesicle proteins. The results indicate that the delivery of the neurotrophic protein CPG15 to the axon surface can be regulated on a rapid time scale by activity-dependent mechanisms in vivo. (C) 2008 Wiley Periodicals, Inc. Develop Neurobiol 68: 744-759, 2008

Keywords: ecliptic pHluorin; in vivo imaging; retinotectal; protein traffic

\section{INTRODUCTION}

The spatial and temporal regulation of mechanisms controlling neuronal growth and synaptogenesis has a significant impact on the development of neuronal circuits. Analysis of the function of the GPI-anchored protein CPG15 (aka neuritin) indicates that it has neurotrophic actions. cpg15 gene expression in cortex of adult rats is induced by sensory activity (Nedivi et al., 1996; Harwell et al., 2005) following activation of NMDAR, CamKII, and CREB (Fujino et al., 2003), and in Xenopus tadpoles following increased activity

HTC is the Marie Robertson Professor of Neuroscience.

Correspondence to: H.T. Cline (cline@cshl.edu).

Contract grant sponsors: Ministerio de Educación y Cultura of Spain, (IC) NIH Director's Pioneer Award, NEI and Dart Neuroscience Inc.

(c) 2008 Wiley Periodicals, Inc.

Published online 28 March 2008 in Wiley InterScience (www. interscience.wiley.com).

DOI 10.1002/dneu.20529 by kainic acid (KA) injection (Javaherian et al., 1998), however expression during early development appears to be insensitive to activity blockade (Corriveau et al., 1999). Furthermore, visually induced expression of cpgl5 in the cortex of adult rats depends on visual experience during development (Lee and Nedivi, 2002), suggesting a complex experience-dependent regulation of $\operatorname{cpg} 15$ gene expression. CPG15 is also induced in the brain following hypoxia (Le Jan et al., 2006), neurotrophin treatment (Pahnke et al., 2004; Lee et al., 2005; Wibrand et al., 2006), androgen treatment (Marron et al., 2005), or neuronal injury (Di Giovanni et al., 2005; Tetzlaff et al., 2006). In addition to the GP1-linked form of CPG15, a soluble form of CPG15 is expressed during early development and appears to function as a survival factor for cortical progenitors (Putz et al., 2005).

CPG15 enhances the development of neuronal dendritic and axonal arbors in vivo (Nedivi et al., 1998; Cantallops et al., 2000) and in vitro (Naeve 
et al., 1997), and accelerates the maturation of glutamatergic synapses in vivo (Nedivi et al., 1998; Cantallops et al., 2000). More recent studies indicate that CPG15 expression in motor neurons is synaptogenic and increases axon arbor elaboration at muscle endplates (Javaherian and Cline, 2005). In vivo studies demonstrate that CPG15 must be attached to the plasma membrane by its GPI anchor to have its neurotrophic effects (Nedivi et al., 1998; Cantallops et al., 2000). Therefore, the mechanisms that control cell-surface CPG15 levels essentially control the function of the GPI-linked form of CPG15. Identification of the mechanisms controlling cell-surface levels of CPG15 is essential to understand the function of the protein and its role in brain development.

GPI-anchored molecules encompass a large group of proteins of great functional diversity (Low, 1989; Field, 1993), including many axon guidance molecules (Walsh and Doherty, 1997). The trafficking mechanisms of GPI-anchored proteins to the plasma membrane, for the most part, have been characterized in nonneuronal cells (Chatterjee and Mayor, 2001). These studies indicate that GPI-anchored proteins follow a "canonical" secretory pathway: GPI-anchored proteins are processed in the ER and trafficked through a population of vesicles in the trans-Golgi network destined for fusion with the plasma membrane (Brown and Rose, 1992; Muñiz and Riezman, 2000; Chatterjee and Mayor, 2001). In neurons, GPIanchored proteins are typically targeted to axons (Harel and Futerman, 1996; Kondoh et al., 1999), although dendritic localization of some GPI-anchored proteins has been reported (Faivre-Sarrailh and Rougon, 1993). Insertion of GPI-anchored proteins into the axonal membrane has been reported to occur along the axon length and at growth cones, and is thought to occur in a constitutive, nonregulated manner (Harel and Futerman, 1996). Once on the plasma membrane, GPI-anchored proteins can be endocytosed, but there is no consensus on the specific endocytic pathway followed (Chatterjee and Mayor, 2001; Nichols et al., 2001; Fivaz et al., 2002). In principle, neurons could utilize their unique properties as excitable cells to regulate the trafficking of GPI-anchored molecules, but this has remained largely unexplored.

To determine the cellular mechanisms governing cell-surface levels of CPG15, we used explant cultures from retina or optic tectum. Such cultures exhibit extensive membrane recycling, including vesicle exocytosis and endocytosis along the length of growing axons (Antonov et al., 1999). This membrane cycling occurs in the absence of postsynaptic partners and likely serves to provide net membrane insertion in the growing axon and release of neurotransmitter, which may play a role in synaptogenesis (Antonov et al., 1999). Consistent with this pattern of membrane trafficking, we find that CPG15 is delivered to and removed from the axon surface in cultured explants by $\mathrm{KCl}$ depolarization.

To observe delivery of CPG15 directly in explants and in intact tadpoles, we expressed a fusion protein of CPG15 and a mutant form of GFP with enhanced $\mathrm{pH}$ sensitivity, the ecliptic pHluorin (Miesenböck et al., 1998; Sankaranarayanan and Ryan, 2000). Experiments with ecliptic pHluorin-CPG15 (EPCPG15) demonstrate that CPG15 is delivered to the axon surface in a depolarization and calcium-dependent manner, whereas GPI-linked YPF does not show comparable activity-dependent trafficking. In addition to its presence on the axon surface (Nedivi et al., 2001), CPG15 colocalized with synaptic vesicle proteins, and by electron microscopy is found in vesicles and endosomes in presynaptic terminals. Our results provide evidence in vivo for an activity-dependent mechanism regulating trafficking of a GPI-anchored protein in neurons, and suggest that the functional availability of CPG15 on the axon surface is controlled by neuronal activity. In contrast to the activity-dependent transcriptional regulation of CPG15 gene expression, the results in this study bring the regulation of CPG15 function by activity into a different temporal realm. Activity-dependent changes in transcription or translation would affect the intracellular pool of CPG15 protein, however activitydependent delivery to and removal from the plasma membrane would control the precise cell-surface bioavailability of the protein.

\section{MATERIALS AND METHODS}

\section{Explant Cultures}

Stage 53-56 albino Xenopus laevis tadpoles were anesthetized with $0.1 \%$ MS222 (Sigma) and both optic nerves were crushed 4 days prior to retinal explant preparation to enhance outgrowth from explants. To prepare explants, eyes were removed from anesthetized tadpoles and placed in ice-cold HBST buffer $(5.8 \mathrm{~m} M \mathrm{NaCl}, 0.6 \mathrm{~m} M \mathrm{KCl}$, $0.3 \mathrm{~m} M \mathrm{CaCl}_{2} \cdot 2 \mathrm{H}_{2} \mathrm{O}, 0.83 \mathrm{~m} M \mathrm{MgSO}_{4} \cdot 7 \mathrm{H}_{2} \mathrm{O}$, and $5 \mathrm{~m} M$ HEPES, pH 7.7). The pigment epithelium and lens were removed, and each retina was cut diagonally into eight pieces, which were plated onto laminin-coated $(5 \%$ in HBST) glass coverslips. Culture media (five parts of L-15, four parts of a solution containing $95 \mathrm{mM} \mathrm{NaCl}, 1 \mathrm{mM}$ $\mathrm{KCl}, 0.6 \mathrm{~m} M \mathrm{CaCl}_{2} \cdot 2 \mathrm{H}_{2} \mathrm{O}, 3.9 \mathrm{~m} M \mathrm{MgSO}_{4} \cdot 7 \mathrm{H}_{2} \mathrm{O}, 4 \mathrm{~m} M$ glutamine, and $9.4 \mathrm{~m} M$ HEPES, and one part of fetal calf serum with $5 \mathrm{ng} / \mathrm{mL}$ sodium selenite, $5 \mathrm{mg} / \mathrm{mL}$ transferrin, $5 \mathrm{mg} / \mathrm{mL}$ insulin, and $1 \%$ penicillin streptomycin) was 
added to the explants $2-4 \mathrm{~h}$ after plating. Explants were used 1-2 weeks later.

Tectal explants were prepared 4 days after in vivo whole brain electroporation to deliver plasmid expressing EPCPG15 as previously described (Foa et al., 2001). Brains were electroporated with $1 \mathrm{mg} / \mathrm{mL}$ DNA solution containing EP-CPG15 expression plasmid (see later). Tecta were dissected from anesthetized Stage 46-47 albino Xenopus laevis tadpoles, rinsed in ice-cold HBST buffer, and individually plated on poly-L-lysine-coated coverslips $(50 \mathrm{mg} /$ $\mathrm{mL}$ in $\mathrm{diH}_{2} \mathrm{O}$, Sigma). Media was added after $2-4 \mathrm{~h}$ and explants were used after 1-2 weeks.

For PI-PLC experiments, culture media was exchanged for PI-PLC (Sigma, $0.4 \mathrm{U} / \mathrm{mL}$ in $10 \mathrm{~m} M$ Tris buffer, $\mathrm{pH}$ 8) or Tris buffer control solution. In preliminary experiments, we observed that 1-h exposure to PI-PLC at RT produced a robust decrease in CPG15 immunoreactivity for this PIPLC concentration. For recovery experiments, explants were rinsed in buffer and then left in the media for different amounts of time before fixation. In order for the PI-PLC to be enzymatically active, we used Tris as buffer, since divalent cations are inhibitory at concentrations ranging from 2 to $10 \mathrm{~m} M$ (Ikezawa and Taguchi, 1981). Tris buffer treatment for $1 \mathrm{~h}$ significantly reduced cell-surface CPG15 to $69 \% \pm 4.7 \%$ of control $(n=9$ in both groups, KruskalWallis $p<0.001$, Mann-Whitney $p=0.015$ ), but PI-PLC further decreased CPG15 levels to $26 \pm 4.8$ of control $(n=$ $10)$. This was a significant reduction when compared with Tris buffer alone or untreated controls (Mann-Whitney $p<$ 0.001). It is possible that the reduction in CPG15 cell-surface levels we observe after Tris treatment alone is due to reduced $\mathrm{Ca}^{++}$-dependent exocytosis of the protein due to baseline levels of activity in the explant cultures.

To depolarize the explants, culture media was exchanged for either a control external solution (1 $\mathrm{m} M$ $\mathrm{KCl}, 118 \mathrm{~m} M \mathrm{NaCl}, 3 \mathrm{~m} M \mathrm{CaCl}_{2}, 3 \mathrm{~m} M \mathrm{MgCl}_{2}, 5 \mathrm{~m} M$ HEPES, $10 \mathrm{~m} M$ glycine, and $10 \mathrm{~m} M$ glucose, $\mathrm{pH}$ 7.7) or a high $\mathrm{K}^{+}$solution $\left(45 \mathrm{~m} M \mathrm{KCl}, 74 \mathrm{~m} M \mathrm{NaCl}, 3 \mathrm{~m} M \mathrm{CaCl}_{2}\right.$, $3 \mathrm{~m} M \mathrm{MgCl}_{2}, 5 \mathrm{~m} M$ HEPES, $10 \mathrm{~m} M$ glycine, and $10 \mathrm{~m} M$ glucose, pH 7.7). In $0 \mathrm{Ca}^{++}$experiments, $3 \mathrm{mM} \mathrm{CaCl} 2$ was replaced by $3 \mathrm{mM} \mathrm{MgCl}$ in the high $\mathrm{K}^{+}$solution, and $2 \mathrm{~m} M$ EGTA was added to chelate $\mathrm{Ca}^{++}$. Osmolarity was adjusted to $255 \mathrm{mOsm}$ in all solutions.

\section{Immunocytochemistry}

For double labeling of cell-surface CPG15 (non-permeabilized conditions) and filamentous actin (with phalloidin, Molecular Probes, under permeabilized conditions), cultures were fixed in $4 \%$ paraformaldehyde in $0.1 \mathrm{M}$ phosphate buffer (PB) for $1 \mathrm{~h}$, and postfixed for $10 \mathrm{~min}$ in fresh fixative. Cultures were rinsed, incubated in 5\% normal goat serum (Vector labs, Burlingame, California) in $\mathrm{PB}$, then in primary antiserum (polyclonal rabbit anti-CPG15, diluted 1:200 in $\mathrm{PB})$. Cultures were rinsed and incubated with FITC-conjugated secondary antibody diluted 1:200 in PB. Subsequently, cultures were rinsed in $\mathrm{PB}$, and in $0.3 \%$ Triton in PB to permeabilize cells, blocked in $5 \%$ normal goat serum in $0.3 \%$ Triton in PB, and then incubated with phalloidin conjugated to RITC (1:800) in $0.03 \%$ Triton in PB. Finally, cultures were rinsed and coverslipped. For double labeling of total CPG15 (permeabilized conditions) or phalloidin (permeabilized conditions) all incubations were done in $0.03 \%$ Triton in PB. For double labeling of cell-surface and total CPG15, cell-surface labeling was done first using a RITC-conjugated secondary antibody, then cultures were permeabilized and incubations were conducted in Triton-containing solutions, using a Cy5-conjugated secondary antibody.

\section{EP-CPG15}

The sequence encoding EP was subcloned from a pGEX-2T plasmid obtained from Dr. G. Miesenböck (Yale University) and inserted either downstream of Xenopus laevis CPG15 signal sequence (atg gga ctt aag ctg agc ggc aga tat atc ttt ctg gtc ctc get gtg cat cta gca tac ctg ctg cag gcg) or upstream of CPG15's GPI anchor sequence (ggg gca ccg gga caa agg ctc cta ttt cca gct ttt ctg cet tta cta atg gtg ttc ctc tct acc cta ttc atc ttg gta ctt cag tag). Six nucleotide restriction site sequences were used as linkers: in $E P-C P G 15$, the signal sequence was flanked by the EcoRI site (gaa ttc) and acc at its $5^{\prime}$ end, and by the StuI site (agg cct) at its $3^{\prime}$ end; EP was flanked by the StuI site at its $5^{\prime}$ end, and by the XhoI site (ctc gag) at its $3^{\prime}$ end; the remaining CPG15 sequence was flanked by XhoI at its $5^{\prime}$ end, and by the XbaI site (tct aga) at its $3^{\prime}$ end. In $C P G 15-E P$, the CPG15 sequence (excluding the GPI anchor) was flanked by the EcoRI site at its $5^{\prime}$ end, and by the StuI site at its $3^{\prime}$ end, $E P$ was flanked by the same sites as in $E P-C P G 15$, and the GPI anchor was flanked by the XhoI site at its $5^{\prime}$ end, and by the XbaI site at its $3^{\prime}$ end. The fusion construct was subcloned into expression vector pCS2+ (provided by Dr. N. Schecter, SUNY), and sequenced for construct verification. The axons expressing EP-CPG15 had comparable responses to depolarizing stimulus as those expressing CPG15-EP. The YFP-GPI fusion was made inserting YFP upstream of the GPI anchor of CPG15.

\section{FM1-43 Labeling}

For these experiments, retinal explants were grown on grided coverslips. Prior to FM1-43 labeling, axons were randomly selected and their grid position noted. Cell culture media was substituted by external solution containing 4 mM FM1-43 (Molecular Probes). To assess FM1-43 unloading, cultures were loaded with FM1-43 for 15 min in the presence of $45 \mathrm{mM} \mathrm{KCl}$ solution, rinsed in external solution for $2 \mathrm{~min}$, and axons were imaged. Cultures were depolarized with $45 \mathrm{mM} \mathrm{KCl}$, imaged again after 2 min, and fixed. After fixation, cultures were processed for CPG15 immunocytochemistry. Imaged axons were identified based on their coverslip grid codes.

\section{In Vivo Retinal Stimulation}

Retinal ganglion cells were transfected by lipofection. DNA solution (1 $\mathrm{mg} / \mathrm{mL})$ containing EP-CPG15 and DsRed1-N1 (Clontech) in a 1:1 ratio was mixed (1:3) with DOTAP lipofectant (Roche) and pressure injected in the 
eye primordium of Stage 20-21 tadpoles (Holt et al., 1990). Animals were screened for those containing one or a few doubly transfected axons 4 days later (Stage 45-46).

Double-labeled axons were imaged on a confocal microscope at 2-mm steps in the $z$-dimension for DsRed1-N1 and EP-CPG15 labeling. The retina was pressure-injected with $20 \mathrm{~m} M \mathrm{KA}$ in external solution, and the axon was imaged again 2 min after the injection. Control animals were uninjected or injected with a mixture of $20 \mathrm{mM}$ KA (Sigma) and $1 \mathrm{~m} M$ tetrodotoxin (TTX, Alomone Labs).

\section{Image Acquisition and Data Analysis}

Immunocytochemistry. Confocal images of the 10 (unless otherwise indicated) brightest axons of each culture at $0.5-\mu \mathrm{m}$ steps were taken. Imaging parameters (laser intensity, brightness, contrast, slit aperture) were set at the beginning of the imaging session for each secondary antibody to ensure that images were collected below pixel saturation values. Once the parameters were set, they were used to image axons of all treatments within the same experiment. Experimental and control cultures were imaged alternatively. When RITC, FITC, or Cy5 were used for double-staining, band-pass filters were used to avoid emission spectra overlap.

To quantify cell-surface/total CPG15 or cell-surface CPG15 values, single frames for every secondary antibody were compiled in a two-image stack. Out of every axon zstack, typically one single frame showed the whole axonal area in focus for both secondary antibodies, and this frame was selected for quantification. Scion Image and customized macros written by Dr. Ed Ruthazer (www.cshl.org/labs/cline/ morphometry.html) were used to measure axon area and average pixel intensity. Axon area was delimited manually following the contour of the axon in the "total CPG15" image, and brightness was measured as the mean gray value contained in this area. The same contour was used in the "cellsurface CPG15" image, by changing the frame in the stack. Mean gray value over background was also measured for every frame and subtracted from the respective measurement over the axon.

EP-CPG15 in Intact Animals. Alternating confocal images were taken of both EP-CPG15 and DsRed1-N1 at 2$\mathrm{mm}$ steps. Imaging parameters were adjusted in the first image for every axon according to expression levels to avoid pixel saturation. The same parameters were kept for imaging after treatment. Quantification was carried out as described earlier for immunolabeled axons. Fluorescence measurements after treatment were normalized to before treatment measurements for every axon.

EP-CPG15 in Tectal Explants. Axons in tectal explants were imaged on a custom-built 2-photon microscope (Ruthazer and Cline, 2002) at 0.5-mm steps. The excitation wavelength was $905 \mathrm{~nm}$. Imaging parameters were optimized for every axon before treatment. Quantification was performed as in immunolabeled axons, on projections of $z$-series stacks. The same number of frames was used to make projections for all the images of every axon. The mean gray value obtained for every axon after treatment was normalized to the mean gray value before treatment.

\section{Electron Microscopy}

Stage 47 tadpoles were anesthetized with $0.2 \%$ MS222. Icecold Steinberg's solution and fixative $(0.6 \%$ paraformaldehyde, $2 \%$ glutaraldehyde, and $0.02 \%$ calcium chloride in $0.035 M$ cacodylate, $\mathrm{pH}$ 7.3) were injected intraventricularly and around the tectal neuropil. Animals were submerged in cold fixative for $1 \mathrm{~h}$, after which brains were dissected out and left in fixative overnight at $4^{\circ} \mathrm{C}$. Brains were then rinsed in $0.035 \mathrm{M}$ cacodylate ( $\mathrm{pH} 7.3$ ), and postfixed in $1 \% \mathrm{OsO}_{4}$ in $0.035 M$ cacodylate for $1 \mathrm{~h}$ at room temperature (RT). This was followed by three 10 -min washes in $0.035 \mathrm{M}$ cacodylate, and one 10-min wash in $\mathrm{diH}_{2} \mathrm{O}$. Brains were dehydrated in 5 -min washes in increasing concentrations of ethanol (30, 50, $70,90,100 \%$ ), and washed three times in a 1:1 ethanol-propylene oxide solution. The tissue was infiltrated in graded concentrations of Epon-Araldite resin, polymerized, sectioned with a microtome at $70-90 \mathrm{~nm}$, and collected on Ni grids.

For postembedding immunohistochemistry, ultrathin sections were hydrated in TBST $(20 \mathrm{~m} M$ Tris at $\mathrm{pH} 7.6,150 \mathrm{~m} M$ $\mathrm{NaCl}, 1 \%$ Tween-20), and incubated overnight with primary antibody solution diluted in TBST (1:5 for polyclonal rabbit anti-CPG15, raised in our laboratory (Nedivi et al., 1998), 1:30 for monoclonal anti-SV2, provided by Dr. K. Buckley, Harvard University). Sections were incubated in secondary antibody solution diluted in TBST (15-nm gold particles, Amersham AuroProbeEM; 1:20). Although postembedding immunogold labeling is characterized by very low detection efficiency (Polak and Varndell, 1984), we used this method because it also has low background and provides the most accurate means to determine subcellular distribution of antigen (Wang et al., 1998). Sections exposed to secondary antibody alone showed $\sim 7$ particles bound per $7.2 \mathrm{~mm}^{2}$ of tissue area (not shown), in contrast with an estimated number of $\sim 3110$ particles per $7.2 \mathrm{~mm}^{2}$ on sections incubated with primary and secondary antibodies. After drying, sections were counterstained with $2 \%$ uranyl acetate for 15-20 min, washed three times in $\mathrm{diH}_{2} \mathrm{O}$, incubated for 2 min in Reynold's lead citrate, washed again in $\mathrm{diH}_{2} \mathrm{O}$, and dried. Grids were examined in an Hitachi H-700 TEM at $75 \mathrm{kV}$.

\section{RESULTS}

\section{Cell-Surface CPG15 is Replenished Following PI-PLC Treatment}

To test the mechanisms by which CPG15 is trafficked to and from the cell surface, we used explant cultures of the retina or optic tectum from which projection neurons extend axons that express CPG15 (Nedivi et al., 2001). By labeling explants with CPG15 antibodies under nonpermeabilized conditions, we can identify cell-surface CPG15 (Fig. 1). Cell-surface 


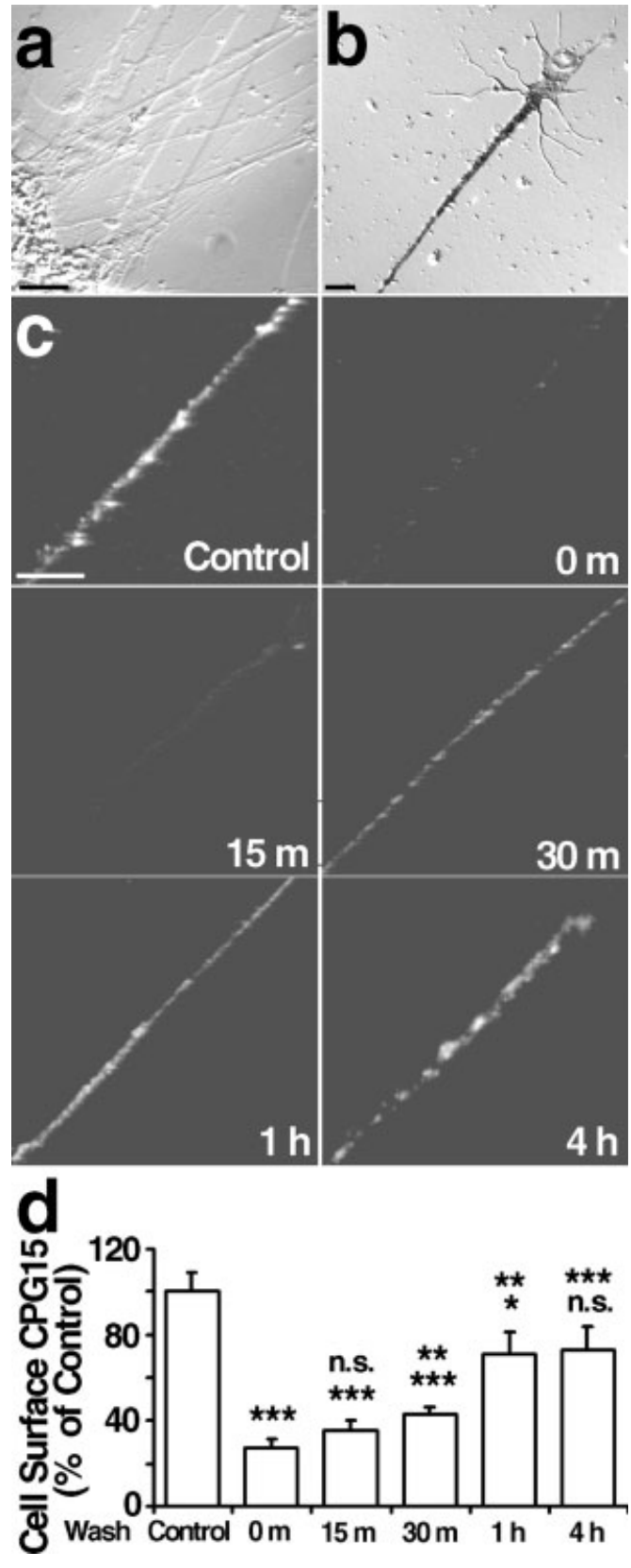

Figure 1 Cleavage of cell-surface CPG15 by PI-PLC. (a) Phase-contrast image of a retinal explant. The retinal explant is in the lower left corner of the panel. The initial segments of axonal bundles and individual axons are observed emanating from the explant. (b) Higher magnification phase-contrast image of a single axon growth cone. (c) Recovery of cell-surface CPG15 levels in axons of different retinal explant cultures following PIPLC treatment. Cell-surface CPG15 was determined by immunocytochemistry in untreated control cultures, and in PI-PLCtreated cultures at different times after PI-PLC washout. (d) Quantification of cell-surface CPG15 normalized to untreated controls. $n=8-10$ axons. * $p<0.05,{ }^{* *} p<0.01$, ***p $p$ 0.001 , and "ns" "not significant". Values were compared with controls (symbols immediately above bars) or to PI-PLC treated axons (top symbols). Scale bar: $50 \mu \mathrm{m}$ (a), $10 \mu \mathrm{m}$ (b and c).
CPG15 is significantly reduced to $27 \% \pm 3.7 \%$ of untreated control values (Kruskal-Wallis $p<0.001$, Mann-Whitney $p<0.001$ ) by 1 -h exposure of cultures to bacterial phosphoinositol-specific phospholipase C (PI-PLC), the enzyme which cleaves GPIanchored proteins (Ikezawa and Taguchi, 1981). After exposure to PI-PLC, explants were returned to normal culture media and fixed at different time points over $4 \mathrm{~h}$. Cell-surface levels of CPG15 were quantified by immunocytochemistry. Cell-surface CPG15 was replenished to values close to control within $4 \mathrm{~h}[73 \pm 11.1 \%$ of control, Mann-Whitney $p=0.06$, Fig. 1(c,d)].

These results demonstrate that changes in CPG15 levels can be quantified by immunocytochemical assays. They also show that endogenous Xenopus CPG15 is indeed a GPI-anchored molecule, as predicted by its sequence (Nedivi et al., 2001), and consistent with other studies which demonstrated that cell-surface CPG15 expressed in CHO cells is cleaved by PI-PLC (Naeve et al., 1997). Finally, this experiment reveals that the protein is trafficked to the cell surface by mechanisms operating over a time course similar to those described for other axonal GPI-anchored molecules (Harel and Futerman, 1996; Pierre et al., 2001).

\section{CPG15 Trafficking to the Axon Surface is Regulated by Activity}

To test whether depolarization affects cell-surface levels of CPG15 relative to total CPG15 protein, we exposed retinal explant cultures to $45 \mathrm{mM} \mathrm{KCl}$ for 2 min, after which cultures were fixed and labeled with CPG15 antibodies first under nonpermeabilized conditions and then under permeabilized conditions using different secondary antibodies. A 2-min exposure to $45 \mathrm{mM} \mathrm{KCl}$ significantly increased the cellsurface/total $\mathrm{CPG} 15$ ratio to $133 \% \pm 9.1 \%$ of untreated controls [Mann-Whitney $p<0.02$, Fig. 2(a,b)]. To test how longer periods of depolarization affects cell-surface levels of CPG15, we exposed retinal explant cultures to $45 \mathrm{mM} \mathrm{KCl}$ for 2,5 , or $15 \mathrm{~min}$, after which cultures were fixed and processed to reveal cell-surface CPG15 and axonal structure [visualized with rhodamine-phalloidin labeled f-actin, Fig. 2(c)]. As aforementioned, the 2-min exposure to $45 \mathrm{mM} \mathrm{KCl}$ increased cell-surface levels of CPG15 compared to untreated control cultures, however this effect was transient, since by 5 min CPG15 levels decreased and by $15 \mathrm{~min}$ they were comparable to baseline. Phalloidin staining indicated that axonal structure was intact throughout the experiment. These 


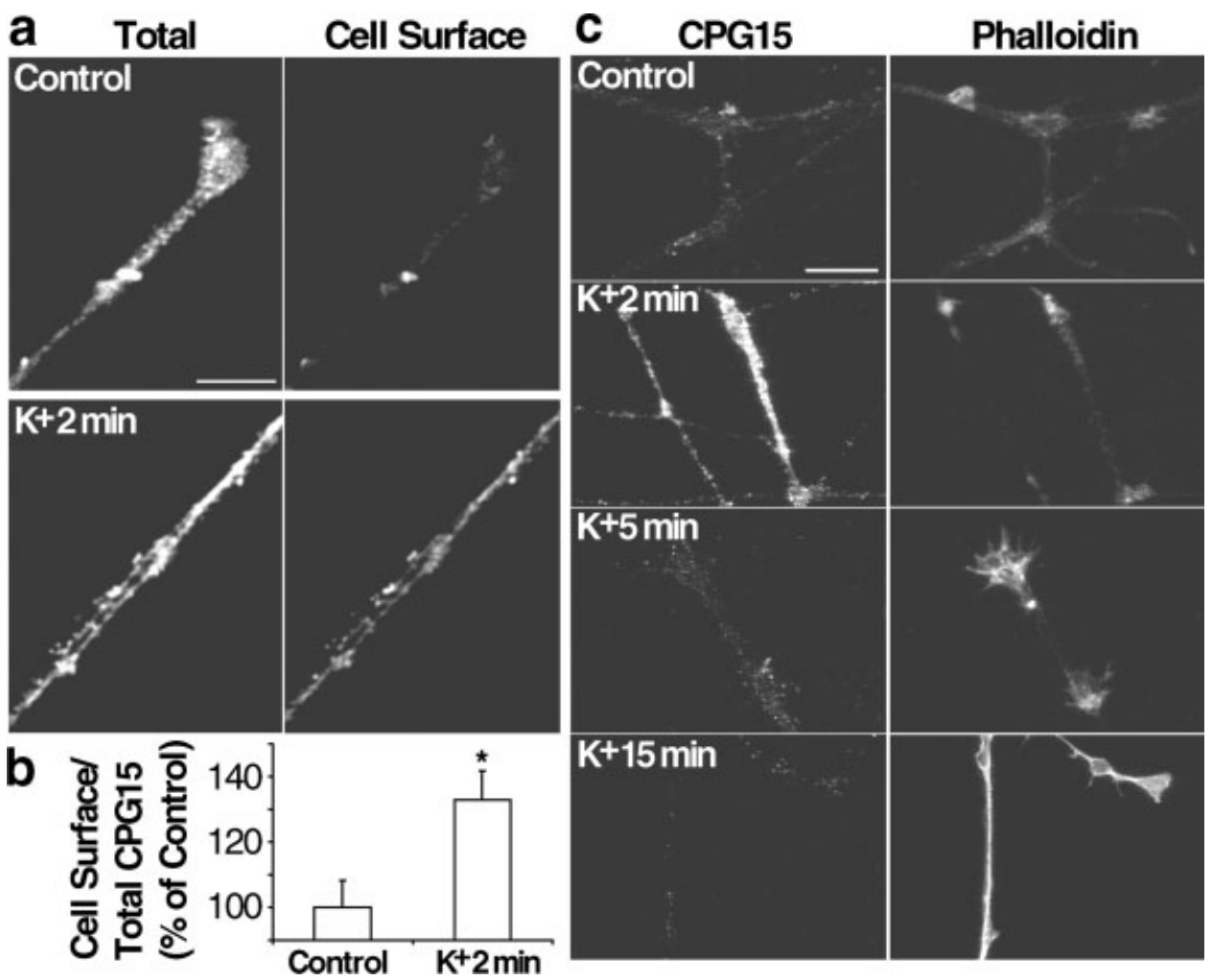

Figure 2 Depolarization causes a transient increase in cell-surface CPG15. (a) Axons doubly immunolabeled for cell-surface and total CPG15 under control conditions and after 2 min of $45 \mathrm{~m} M \mathrm{KCl}$. (b) Quantification of results exemplified in cell-surface CPG15 is normalized to total CPG15 levels, and to the control, untreated group. $n=10$ axons. $* p<0.05$. (c) Axons were double-labeled for cell-surface CPG15 and polymerized actin (phalloidin) under control conditions or at different times after $45 \mathrm{mM} \mathrm{KCl}$ exposure. Scale bar: $20 \mu \mathrm{m}$ (c), $10 \mu \mathrm{m}$ (a).

experiments show that depolarization significantly increases cell-surface CPG15. In addition, longer periods of depolarization lead to a decrease in cellsurface CPG15 that may result from activity-dependent endocytosis.

To test whether endocytosis of CPG15 is activitydependent, we exposed retinal explant cultures to $45 \mathrm{~m} M \mathrm{KCl}$ for $2 \mathrm{~min}$ and then returned the cultures to external solution for different periods up to $1 \mathrm{~h}$. When cultures were depolarized for $2 \mathrm{~min}$ and returned to normal external solution for $13 \mathrm{~min}$, the cell-surface/total CPG15 ratio was significantly higher (135 \pm 6.8\%; Kruskal-Wallis $p<0.001$, Mann-Whitney $p=0.032$ ) than controls. Cell-surface/total CPG15 ratios remain elevated for at least $30 \mathrm{~min}$ after the $2-\mathrm{min} \mathrm{KCl}$ treatment in the absence of further depolarization, and decrease to basal levels within $1 \mathrm{~h}$ (Fig. 3). These experiments suggest that reduction of cell-surface CPG15 with continuous depolarization (Fig. 2) is due to endocytosis of protein by an activity-dependent mechanism. In the absence of sustained depolarization by $\mathrm{KCl}$, reduction of cell-surface CPG15 occurs at a slower rate. Although a soluble isoform of CPG15 has been reported in mice (Putz et al., 2005), we have not observed this form of CPG15 in Xenopus, and it is unlikely that the decrease in cell-surface CPG15 is due to cleavage of the GPI-linked CPG15.

\section{CPG15 Exocytosis is Calcium-Dependent}

The experiments described so far have the advantage that they assess the trafficking of endogenous CPG15, however the conclusions are based on comparisons between treatments in different cultures, since they have to be performed on fixed cultures. To observe CPG15 trafficking directly in living axons, we constructed a fusion protein of CPG15 and a highly $\mathrm{pH}-$ sensitive form of green fluorescent protein, ecliptic pHluorin (Miesenböck et al., 1998). Fluorescence emission from ecliptic pHluorin (EP) is decreased at acidic 


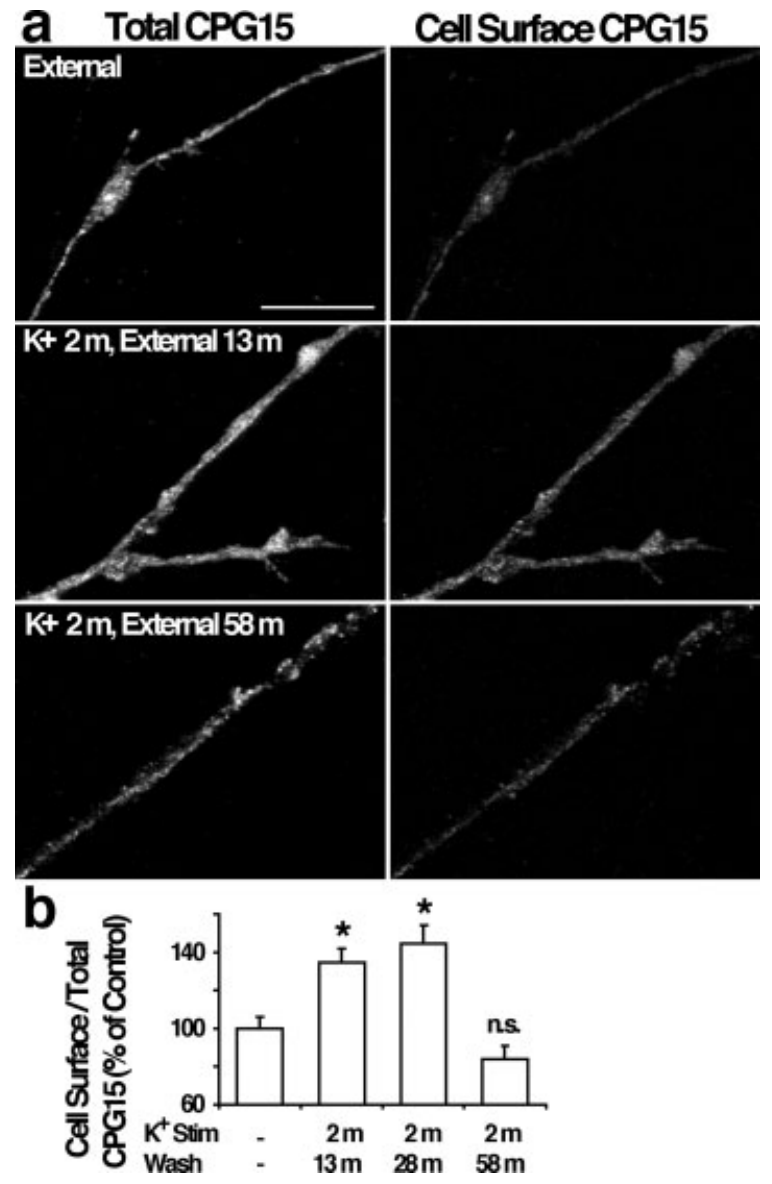

Figure 3 CPG15 is endocytosed by an activity-dependent mechanism. (a) Cultures were depolarized in 45-mM KCL for $2 \mathrm{~min}\left(\mathrm{~K}^{+} 2 \mathrm{~m}\right)$ and washed in external for the periods indicated. Axons were double-labeled for total CPG15 (left panels) and cell-surface CPG15 (right panels). (b) Quantification of cell-surface/total CPG15 expressed relative to control group. $n=4-17$ axons. $* p<0.05$, "ns" "not significant." Scale bar: $20 \mu \mathrm{m}$.

$\mathrm{pH}$. Therefore, EP-CPG15 located in vesicles and other endocytic compartments which have an acidic $\mathrm{pH}$ is not detected (Miesenböck et al., 1998; Sankaranarayanan and Ryan, 2000). EP-CPG15 fluorescence becomes detectable once the protein is delivered to the cell surface due to the neutral $\mathrm{pH}$ of the extracellular milieu. Therefore, this construct allows us to monitor cell-surface levels of CPG15 under different treatments for the same axons and to carry out the experiments in vivo on axons of transfected cells.

We fused the fluorescent marker EP either downstream of the signal sequence of CPG15 (EP-CPG15), or upstream of the GPI consensus sequence (CPG15EP) [Fig. 4(a)]. Both fusion proteins resulted in identical patterns of labeling in retinal ganglion cell axons, although the form with EP at the N-terminus of the mature protein (EP-CPG15) was consistently brighter, and was therefore used for most of the following experiments. In all cell types examined, including tectal, telencephalic, and spinal cord neurons, the distribution of EP-CPG15 at the cell body had a characteristic ring pattern, similar to the distribution of GP1-anchored YFP (not shown). This is consistent with the cell-surface distribution expected for GPI-anchored proteins (Low, 1989) and with that previously observed in another GPI-anchored protein fused to EP (Miesenböck et al., 1998). EP-CPG15 was observed in a characteristic patchy distribution along the axon in explant cultures [Fig. 4(c)] and along the axonal shaft and the axon arbor in vivo (Fig. 5), comparable to the distribution of the endogenous cell-surface CPG15 seen by immunolabeling. The patchy distribution could arise from delivery at sites of vesicle fusion and restricted lateral mobility of GPI-anchored proteins because of their association with lipid rafts (Simons and Toomre, 2000). As previously reported (Miesenböck et al., 1998; Sankaranarayanan and Ryan, 2000), exposure of labeled cells in tectal explants to acidic media $(\mathrm{pH}=$ 5) resulted in a rapid and dramatic loss of EP-CPG15 fluorescence (not shown). Both this result and the pattern of labeling of EP-CPG15 in the neuronal cell bodies are consistent with a cell-surface location of the fluorescent signal.

To test the calcium-dependence of CPG15 delivery, we used tectal explant cultures expressing EP-CPG15. We imaged the axons from explants on a 2-photon microscope before and after exposure to $45 \mathrm{mM} \mathrm{KCl}$ in the presence or absence of external calcium. Depolarization by $45 \mathrm{mM} \mathrm{KCl}$ for $2 \mathrm{~min}$ significantly increased EP-CPG15 fluorescence along the length of the axon (Kruskal-Wallis $p<0.001$, Mann Whitney $p=0.027$, Fig. 4), as seen with the delivery of endogenous CPG15. Activity-dependent delivery of EP-CPG15 to the axon surface requires extracellular calcium (Fig. 4). These results indicate that CPG15 is delivered to the axon surface by a depolarization-dependent mechanism.

\section{CPG15 Delivery to the Axon Surface In Vivo is Activity-Dependent}

To test the activity-dependent delivery of EP-CPG15 to the axon surface in intact tadpoles, we introduced the plasmid encoding EP-CPG15 and a second plasmid encoding a cytosolic protein, DsRed1-N1 (Baird et al., 2000) in the eye primordium of Stage 20-21 tadpoles by lipofection. Four days later, at stage 47 , animals were screened to select those with one or few 

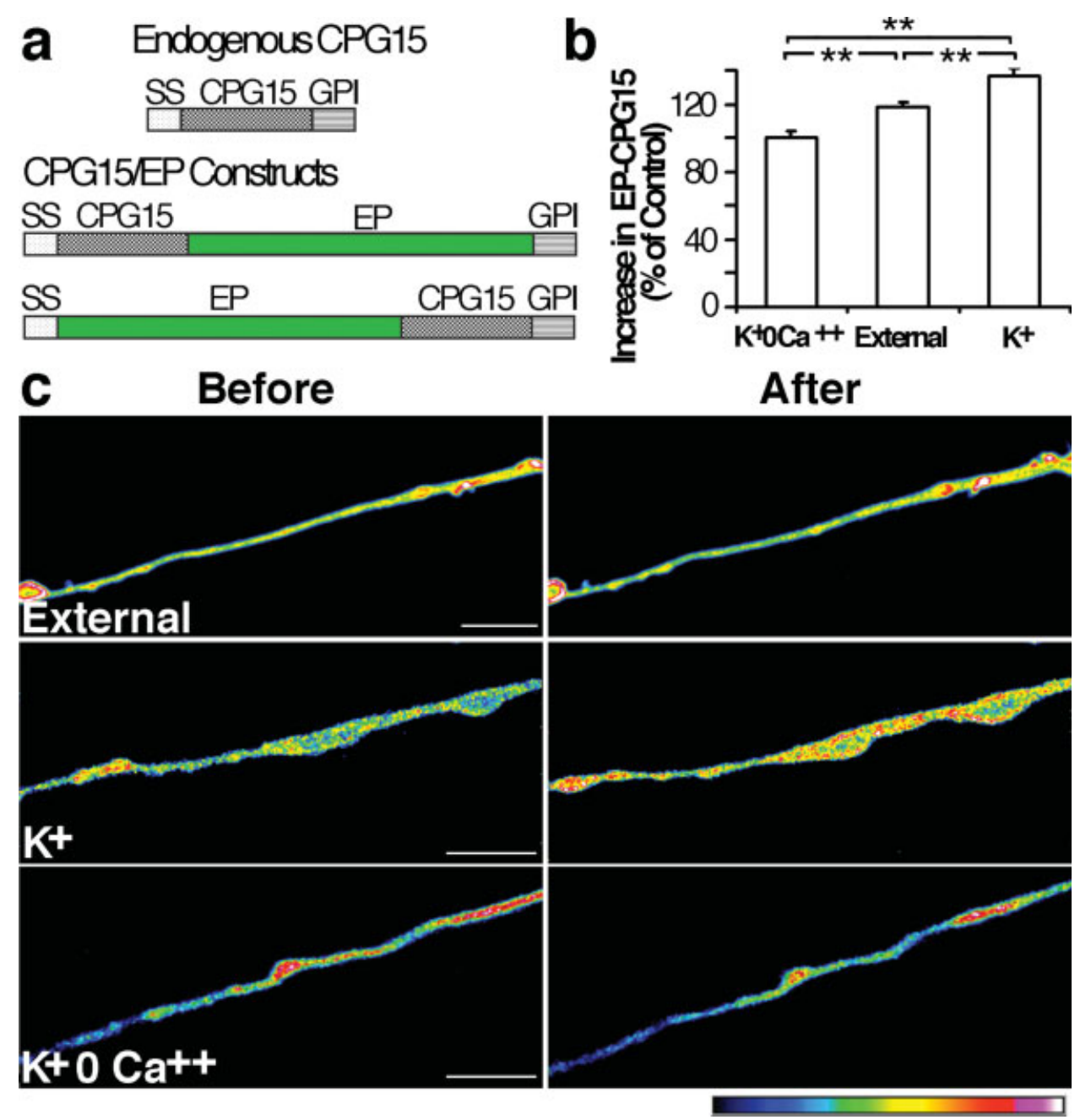

Figure 4 CPG15 exocytosis is $\mathrm{Ca}^{++}$-dependent. (a) Schematic representation of CPG15 structure and EP/CPG15 fusion proteins. SS stands for signal sequence in the N-terminus, and CPG15 represents the mature protein, without the SS or the GPI anchor sequences. (b) Relative change in EP-CPG15 compared to initial values with different treatments exemplified in (c). $n=6-10$ axons.

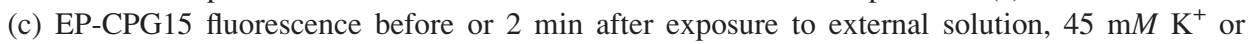
$45 \mathrm{~m} M \mathrm{~K}^{+}$in $0 \mathrm{Ca}^{++}$. Images were pseudocolored according to the color lookup table, where black is 0 and white is 255 . $* * p<0.01$. Scale bar: $10 \mu \mathrm{m}$.

retinal axons in the tectum that expressed both constructs. Axons were then imaged on the confocal microscope for both EP-CPG15 (green) and DsRed1N1 (red) signals, before and 2 min after depolarization of retinal cells by intraocular injection of $20-\mu \mathrm{M}$ KA. EP-CPG15 fluorescence increased significantly to $167 \% \pm 14 \%$ of untreated controls (Kruskal Wallis $p=0.002$, Mann-Whitney $p=0.001$ ) following KA injection into the eye, whereas DsRed1-N1 fluorescence did not change $(107 \pm 7.2 \%$ of untreated controls, Kruskal Wallis $p=0.391)$. Note that highest EP-CPG15 fluorescence increases occur at discrete spots, potentially corresponding to sites of vesicle exocytosis [Fig. 5(c)]. When EP-CPG15 fluorescence was normalized to DsRed1-N1 fluorescence, the average fluorescence was significantly increased to $160 \% \pm 17.2 \%$ of control [Kruskal-Wallis $p=$ 0.002, Mann-Whitney $p=0.002$; Fig. 5(d)].

To test whether the increased EP-CPG15 fluorescence following KA-injection was due to increased action potential activity in retinal ganglion cells, we coinjected KA with the voltage-dependent sodium channel blocker tetrodotoxin (TTX). Coinjection of TTX with KA blocked the increased EP-CPG15 fluorescence $(112 \pm 19.5 \%$ of control, Mann Whitney $p=0.709)$, and blocked the increased ratio of CPG15 to DsRed1-N1 fluorescence (96 $\pm 15.3 \%$ of control, Mann-Whitney $p=0.823$ ) seen with KA injection 


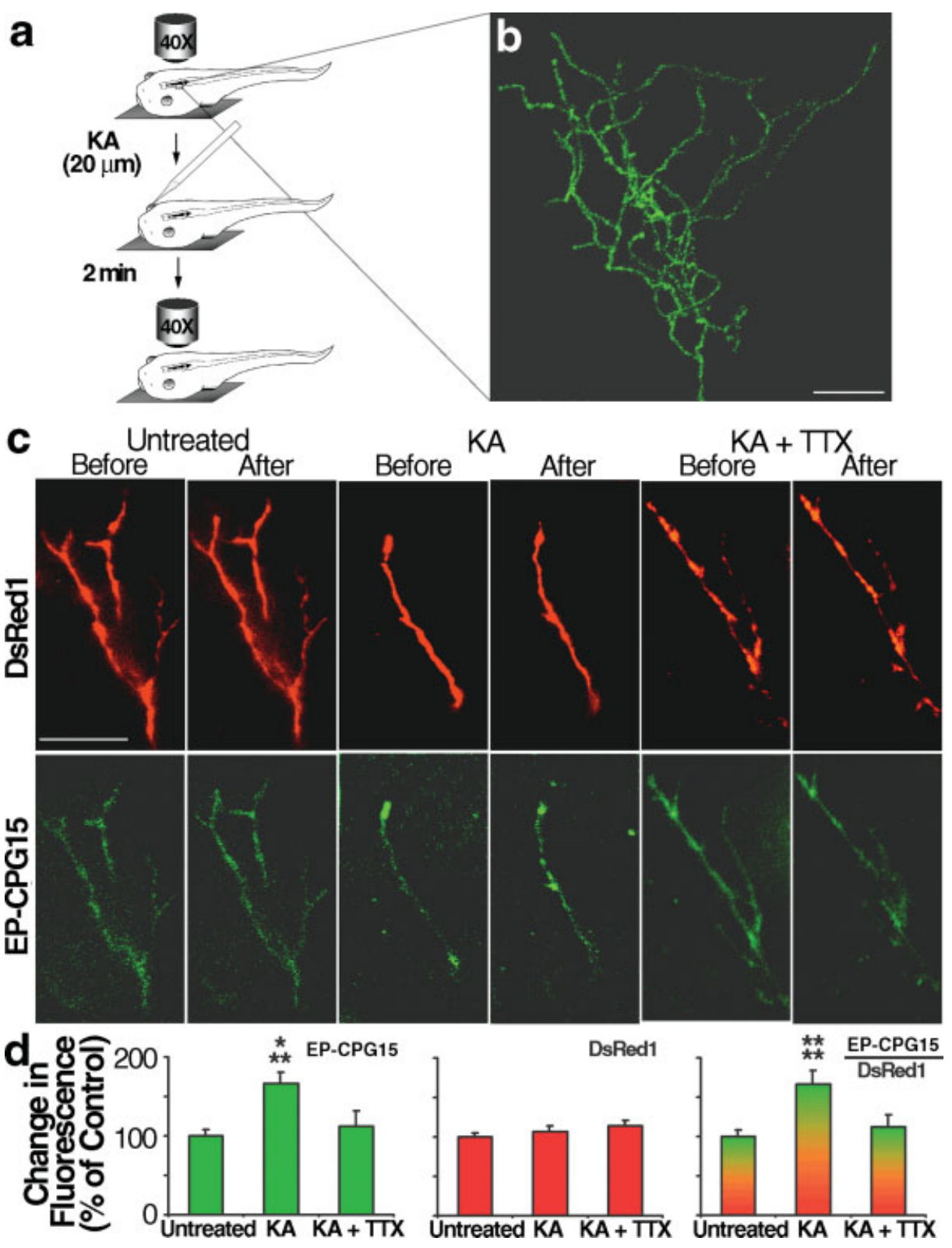

Figure 5 Cell-surface EP-CPG15 increases on retinal ganglion cell axons of intact tadpoles after 2-min KA treatment. (a) Schematic representation of the experimental protocol. (b) Projection of a single retinotectal axon expressing EP-CPG15 imaged on a 2-photon microscope. (c) Images of DsRed1-N1 and EP-CPG15 fluorescence before and 2 min after specified treatments. (d) Quantification of before/after fluorescence ratios for the proteins indicated, or their ratio, normalized to the average of the untreated control group. $n=7-15$ axons. ${ }^{*} p<0.05,{ }^{*} p<0.01$. Scale bar: $20 \mu \mathrm{m}$ (b, c).

alone. The results demonstrate directly that depolarization of retinal ganglion cells in vivo causes a rapid increase in cell-surface CPG15.

\section{Subcellular Distribution of CPG15}

We previously reported that CPG15 immunoreactivity is strong in axon tracts and in the retinotectal neu- ropil (Nedivi et al., 2001). To determine the subcellular distribution of CPG15 within axons, we tested whether CPG15 colocalizes with synaptic vesicle protein, SV2 in retinal explant cultures. CPG15 immunoreactivity is punctate along the length of the axon and in growth cones and colocalizes with the synaptic vesicle protein, SV2 (Fig. 6). SV2 immunoreactivity appears as puncta along the length of retinal axons in explant cultures. Because these cultures lack 


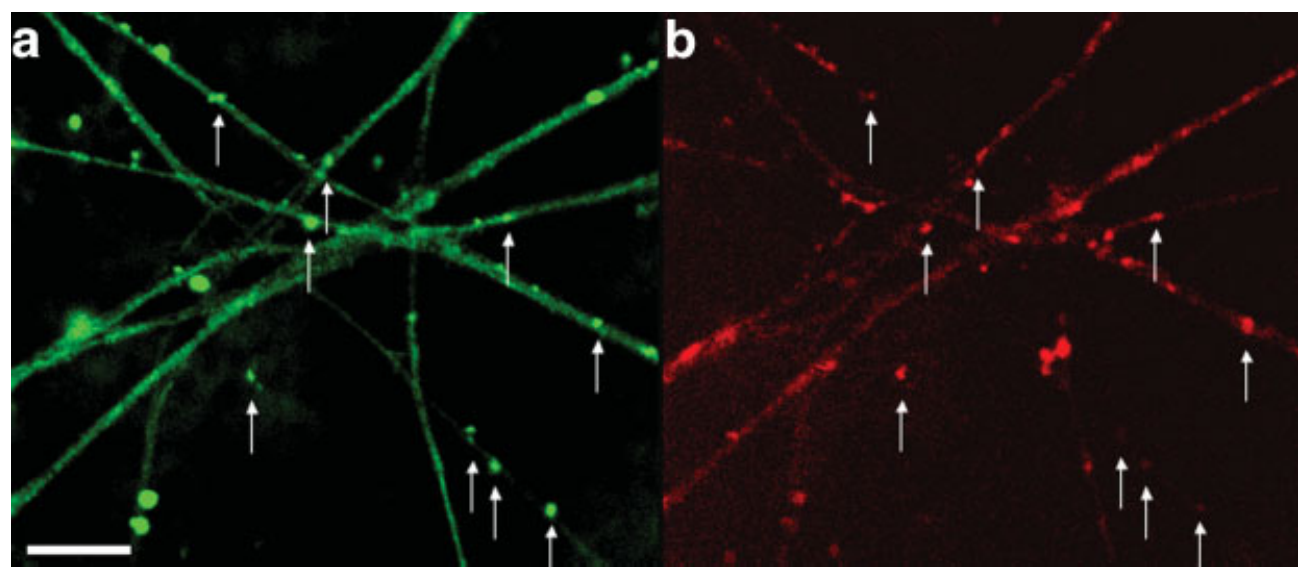

Figure 6 CPG15 colocalizes with synaptic vesicle protein. CPG15 (a) and SV2 (b) immunoreactivity in retinal explant cultures. Arrows indicate co-distribution of SV2 puncta and dense CPG15 immunoreactivity. Cell-surface CPG15 is relatively diffuse, as seen in Figures 1 and 2. Scale bar: $10 \mu \mathrm{m}$.

postsynaptic neurons, the SV2 puncta are not likely to be bonafide synapses but are more likely sites of vesicle accumulation. The colocalization of CPG15 and synaptic vesicle protein, together with the observation (Fig. 2) that a 15-min exposure to $45 \mathrm{mM} \mathrm{KCl}$ results in a transient increase and then removal of CPG15 from the axon surface, suggests that CPG15 is cycled to and from the axon surface through vesicular compartments in the axon by activity. To test whether intracellular CPG15 within vesicular compartments is delivered to the cell surface with depolarizing stimuli, we labeled explants with the lipophilic dye FM1-43. FM1-43 is a styryl dye that reversibly binds to membranes, and when bound shows higher fluorescence than in solution (Cochilla et al., 1999). FM1-43 has traditionally been used to study dynamic recycling of synaptic vesicle membrane at synaptic terminals (Cochilla et al., 1999), where upon brief depolarization, FM1-43 bound to the plasma membrane is endocytosed into synaptic vesicles. Synaptic vesicle exocytosis can then be observed as a decrease in FM1-43 fluorescence following a second exposure to depolarizing stimuli. However, longer loading protocols allow the visualization of additional cycling membrane compartments including endosomes and their derivative vesicles (Maletic-Savatic et al., 1999). We exposed retinal explant cultures to FM143 in the presence of $45 \mathrm{mM} \mathrm{KCl}$ for $15 \mathrm{~min}$ to label endocytosed compartments of CPG15. This protocol labeled vesicular structures along the length of retinal axons with FM1-43 (Fig. 7). After rinsing the explants with external solution, a 2-min exposure to $45 \mathrm{mM} \mathrm{KCl}$ decreased FM1-43 labeling due to vesicle exocytosis. The cell-surface distribution of CPG15 shows a patchy distribution, parts of which match the sites of vesicle exocytosis revealed by FM1-43 destaining [blue stars in Fig. 7(c)]. These results support the hypothesis that intracellular CPG15 is localized in vesicles and is trafficked to and from the axon surface with depolarizing activity.

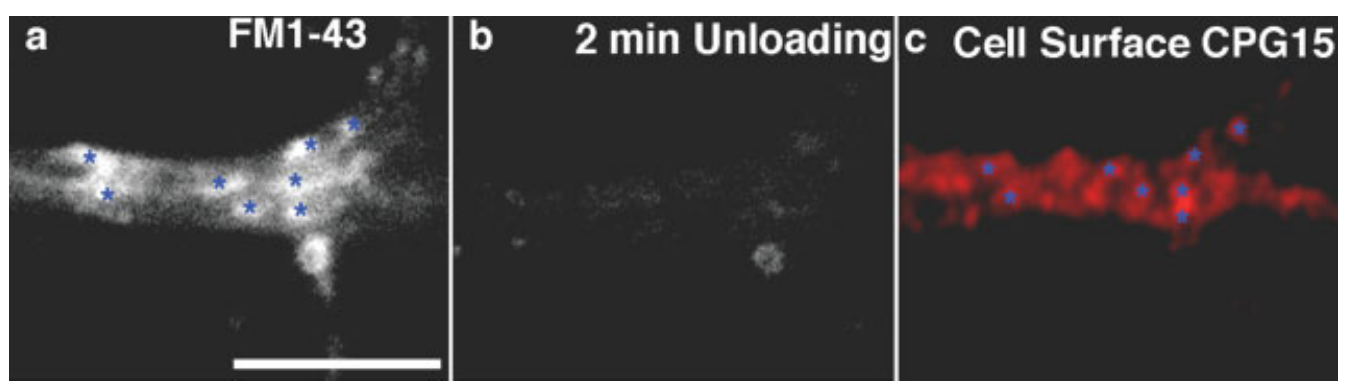

Figure 7 CPG15 colocalizes with FM1-43 cycling sites. FM1-43 labeling (a) and unloading (b) in live cultures, and CPG15 immunoreactivity of the same region after fixation (c). Co-distribution of FM1-43-labeled compartments with CPG15 is shown with blue stars. Note that the tissue is distorted after fixation. Scale bar: $10 \mu \mathrm{m}$. 


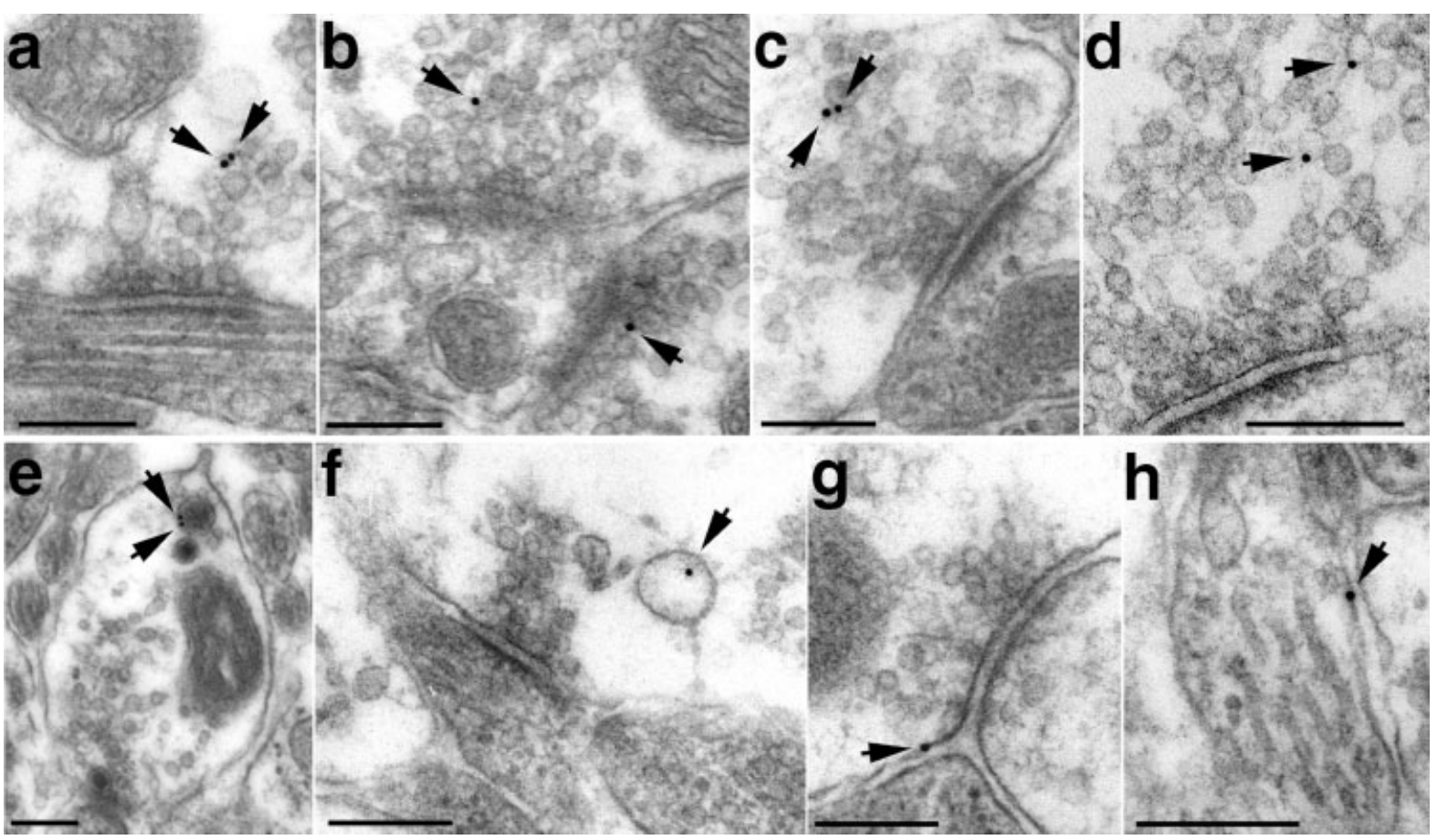

Figure 8 Ultrastructural localization of CPG15 in tectal neuropil of stage 47 Xenopus laevis tadpoles. CPG15 (arrows in a-c, and e-h) is found in small clear presynaptic vesicles $(\mathrm{a}-\mathrm{c}$ ) which resemble synaptic vesicles labeled with synaptic marker SV2 (arrows in d). CPG15 (arrows) is also found in dense-core vesicles (e), endosomes (f), axon membranes (g), and dendrites (h). Tissue was processed for postembedding immunogold electron microscopy. Scale bar: $0.25 \mu \mathrm{m}$.

We used postembedding immunogold labeling and electron microscopy to determine the ultrastructural distribution of CPG15 in the retinotectal neuropil of the optic tectum of tadpoles, where retinal ganglion cell axons form synapses with optic tectal cell dendrites (Rybicka and Udin, 1994; Yen et al., 1995). Intracellular CPG15 immunoreactivity was associated with presynaptic terminals, where gold particles were localized to small clear presynaptic vesicles [Fig. 8(a)], which also label for the synaptic vesicle protein SV2 [Fig. 8(d)], dense core vesicles [Fig. 8(e)], and endosomes [Fig. 8(f)]. As previously observed in light microscopy studies (Nedivi et al., 2001), CPG15 immunoreactivity labeled axonal membrane, characteristic of GPI-anchored proteins [Fig. 8(g)].

We measured the distribution of gold particles within five $10 \mu \mathrm{m} \times 10 \mu \mathrm{m}$ regions of the tectal neuropil, which is highly enriched with retinotectal synaptic contacts. These regions had $42 \pm 5$ gold particles $/ 100 \mu \mathrm{m}^{2}$, compared to $0.94 \pm 0.15$ gold particles $/ 100 \mu \mathrm{m}^{2}$ in the cell body region of tectum. For the organelles that we could identify, half of immunogold particles colocalized with small clear vesicles at presynaptic terminals. About $12-15 \%$ of particles colocalized each with dense core vesicles and endo- somes, $10 \%$ with perisynaptic membrane, and $10 \%$ with microtubules, within axons or dendrites. About $5 \%$ of gold particles in the neuropil were associated with mitochondria, which we assume represents nonspecific binding. These values are approximate, because about $30 \%$ of all gold particles in the neuropil were associated with subcellular structures, that we could not identify with confidence.

The intracellular distribution of CPG15 in presynaptic vesicles is consistent with our observations that the protein is delivered to the axon surface by activity-dependent mechanisms. Furthermore, the presence of CPG15 in endosomes supports the idea that the protein may be removed from the cell surface by endocytosis.

\section{DISCUSSION}

\section{Protein Trafficking Assessed by Ecliptic pHluorin Fusion Protein Expression}

Since the realization that the $\mathrm{pH}$ sensitivity of GFP could be used to track changes in the distribution of GFP-tagged proteins and the systematic optimization of GFP to maximize its change in fluorescence under 
different $\mathrm{pH}$ conditions (Miesenbock and Rothman, 1997), the resultant GFP variant, ecliptic phluorin (EP) has been fused to a variety of cell-surface proteins to assess mechanisms of protein trafficking to and from the plasma membrane (Meyer and Oancea, 2000; Siegel and Isacoff, 2000). Most intracellular membrane compartments are sufficiently acidic to quench EP fluorescence. Within the secretory pathway, membrane compartments become more acidic as they progress from the endoplasmic reticulum $(\mathrm{pH}$ 7.2) through the Golgi (cis-Golgi, pH 6.7; transGolgi, $\mathrm{pH}$ 6.0). Secretory granules range from $\mathrm{pH} 5.7$ to 5.0 depending on whether they are in the constitutive or regulated pathway (Kneen et al., 1998; Llopis et al., 1998; Paroutis et al., 2004). Endocytic compartments, through which proteins and lipids can be removed from and recycled to the plasma membrane, are rapidly acidified, to achieve $\mathrm{pH}$ ranging from 5.9 to 6.0 in endosomes, $\mathrm{pH} 5.0$ to 6.0 in late endosomes, and about $\mathrm{pH} 6.5$ in recycling endosomes (Maxfield and McGraw, 2004). Acidification of endosomes appears to be a general requirement for protein trafficking (Maxfield and McGraw, 2004), and endosomal compartments with neutral $\mathrm{pH}$ have not been observed, unless they are still in contact with the extracellular medium (Yamashiro and Maxfield, 1984). Indeed, the $\mathrm{PH}$ of endosomes in neuronal axons was measured at pH 5.8-6.2 (Overly and Hollenbeck, 1996).

Originally, EP was fused to synaptic vesicle proteins (Miesenbock and Rothman, 1997) so that the EP moiety was harbored within the vesicle, where the acidic $\mathrm{pH}$ quenches the fluorescence of the EP. When the synaptic vesicle fuses with the plasma membrane, exposure of the EP to the extracellular environment, which is relatively $\mathrm{pH}$-neutral, permits fluorescence of the EP. Several labs have made great use of EP or pHluorin-tagged synaptic vesicle proteins to examine the mechanisms of redistribution and capture of synaptic vesicle proteins during synaptic transmission (Fernandez-Alfonso and Ryan, 2004; Li et al., 2005; Atluri and Ryan, 2006; Granseth et al., 2006). These same reagents have provided powerful tools for the examination of synaptic transmission in intact systems, including the olfactory projections of mice (Bozza et al., 2004) and Drosophila (Shang et al., 2007), and are likely to allow a system level analysis of synaptic activity in relation to complex stimuli and behavioral paradigms. To generalize, pHluorintagged transmembrane proteins can be very informative in studies of trafficking from intracellular compartments to the plasma membrane. pHluorin-tagged transferin receptors have been used to visualize mobility of proteins through dynamic endocytotic com- partments in nonneuronal cells (Merrifield et al., 2005) and neurons (Park et al., 2006). pHluorins have also been fused to other vesicular proteins, for instance, to examine secretion of insulin (Ohara-Imaizumi et al., 2002). As another example, ecliptic pHluorin fusion proteins of neurotransmitter receptors have recently demonstrated the delivery and removal of receptors to and from the cell surface (Ashby et al., 2004; Bouschet et al., 2005; Jacob et al., 2005). This study broadens the application of ecliptic pHluorins to study the mobility of GPI-linked proteins, and demonstrates that GPI-linked proteins are harbored in acidic intracellular compartments prior to activity-dependent delivery to the axon surface. Furthermore, our in vivo results with superecliptic pHluorin-tagged CPG15 demonstrate the widespread distribution of vesicle fusion sites along retinal axons in the intact animal, in support of previous work indicating that vesicle fusion in growing axons is not restricted to obvious synaptic sites (Zakharenko et al., 1999). It is now clear that protein exocytosis and endocytosis are key regulatory mechanisms for a wide variety of signaling events in neurons and nonneuronal cells (Kennedy and Ehlers, 2006), and that pHluorins will be valuable reagents in the examination of regulatory mechanisms controlling dynamics of protein trafficking in and out of cells.

\section{Activity-Dependent Trafficking of CPG15}

We report that the GPI-linked protein CPG15 is trafficked to the axonal membrane by an activity-dependent mechanism both in explant cultures and in intact animals. This trafficking behavior of CPG15 differs from that previously reported for other GPI-anchored proteins in that it cycles to and from the axon surface by a calcium-dependent mechanism, and an intracellular pool of CPG15 in axons is associated with vesicles and endosomes. Cell-surface delivery of CPG15 to retinotectal axons occurs all along the axon length, consistent with previous studies showing that calcium-dependent vesicle cycling can occur all along growing axons, independently of apposition to postsynaptic structures (Matteoli et al., 1992; Dai and Peng, 1996; Antonov et al., 1999). Therefore, trafficking of CPG15 in explant cultures appears to take advantage of exocytotic machinery (Zakharenko et al., 1999) but is not necessarily limited to bonafide synaptic sites. Synaptic vesicles may accumulate CPG15 from the axon surface by virtue of the high degree of local membrane cycling at synaptic sites (Lin and Scheller, 2000).

Although CPG15 continuously cycles to and from the plasma membrane with activity, we were able to 
detect a net increase of about $30 \%$ in the cell-surface/ total ratio of CPG15 followed by a decrease during sustained depolarization. While endocytotic mechanisms of GPI-anchored proteins in nonneuronal cells are still a matter of debate (Chatterjee and Mayor, 2001), our results suggest that neurons take advantage of their excitable properties to regulate endocytosis of CPG15 in an activity-dependent manner. Considering that we observe both delivery and removal of CPG15 from the plasma membrane with depolarization, our observation suggests that the initial balance of exocytosis to endocytosis is shifted toward net exocytosis with depolarization. Although blocking endocytosis might be expected to result in an increase in cell-surface CPG15, other studies have demonstrated that blocking endocytosis can also affect delivery of protein to the plasma membrane, possibly by interfering with trafficking through recycling endosomes.

Endocytosis has recently become appreciated as a complex means to control cell-surface expression of plasma membrane proteins (Kennedy and Ehlers, 2006). In axon guidance, L1-mediated adhesion is regulated by endocytotic control of cell-surface levels of L1 (Long et al., 2001). Recent data indicate that activation of guidance molecules, such as semaphorin receptors, can lead to a coordinated endocytosis of the receptor, neuropilin, along with the associated L1-adhesion molecule (Castellani et al., 2004; Piper et al., 2005). This enables spatio-temporal control of response to axon guidance cues along with a decrease in adhesion necessary for changes in growth cone behavior. Cell-surface levels of key regulatory proteins can be replenished by mechanisms requiring protein synthesis (Piper et al., 2005; Piper et al., 2006) or local delivery from recycling endosomes (Park et al., 2006).

\section{Recovery of Cell-Surface CPG15 After PI-PLC}

We have shown that CPG15 is found on the surface of axons in Xenopus neurons where it can be cleaved by exogenous PI-PLC, two features that are diagnostic for GPI-anchored proteins (Faivre-Sarrailh and Rougon, 1997; Chatterjee and Mayor, 2001). Cellsurface levels of CPG15 are replenished following PI-PLC application over a time course of hours, more quickly than the rates reported for other GPI-anchored molecules in axons (Harel and Futerman, 1996; Pierre et al., 2001) and in nonneuronal cells (Lisanti et al., 1990). The more rapid rate of recovery of cell-surface CPG15 compared to other axonal GPI- anchored proteins (Harel and Futerman, 1996; Pierre et al., 2001) could reflect a contribution by the rapid activity-dependent component of delivery due to basal levels of electrical activity in the explant cultures.

\section{Functional Implications of Activity-Dependent CPG15 Trafficking}

The data indicate that cell-surface levels of CPG15 can be quickly increased coincident with the same axonal activity that would result in synaptic transmission. A recent study suggests that a netrin, a classic guidance molecule, and brain-derived neurotrophic factor (BDNF) can depolarize axonal growth cones and induce calcium influx through activation of transient receptor potential (TRP) channels (Wang and Poo, 2005). The source and magnitude of depolarization of axons in vivo that might regulate cell-surface levels of CPG15 are not yet known, however local depolarization, for instance by BDNF, or action potentials triggered by visual activity are reasonable candidates. BDNF is known to affect Xenopus retinal axon structural plasticity (Hu et al., 2005), and it is possible that BDNF and CPG15 may have cooperative effects in retinotectal development. The lifetime of CPG15 on the axon surface is also controlled by activity, such that maintained levels of activity reduce surface levels of CPG15 due to endocytosis.

What might be the functional consequences of activity dependent control of cell-surface CPG15 levels? Our previous studies have shown that CPG15 expression increases the elaboration of both tectal cell dendritic arbors and retinal ganglion cell axon arbors and also increases the strength of retinotectal synaptic transmission. All these functions of CPG15 occur in a noncell autonomous manner and require that the protein be tethered to the cell surface by the GPI anchor. These data, together with the predominant localization of CPG15 in axons, suggest that CPG15 functions as a signaling molecule with neurotrophic activity. These new results, demonstrating a rapid, activity-dependent trafficking of CPG15 to the axon surface, suggest that CPG15 may exert its neurotrophic effects under strict spatiotemporal control, so that enhanced synaptic function can be coordinated with pre- and postsynaptic structural plasticity.

Many GPI-anchored proteins play a prominent role in axon guidance (Walsh and Doherty, 1991; Faivre-Sarrailh and Rougon, 1997; Knoll and Drescher, 2002) and some are involved in synaptic plasticity (Gao et al., 1998; Murai et al., 2002). It is interesting to note that GPI-anchored proteins are 
sorted into lipid microdomains called rafts (Brown and Rose, 1992; Simons and Toomre, 2000), which are thought to be organized functional signal transduction complexes. This suggests that GPI-linked proteins and associated signaling complexes may be dynamically regulated within the axon membrane. The observation that F3/contactin localizes to putative synaptic boutons at the light microscope level (Pierre et al., 2001) suggests that its distribution within axons may also be governed by activity. It would be interesting to test whether the spatiotemporal distribution of other GPI-anchored proteins on the neuronal surface is also tightly regulated by activity.

We thank Dr. K. Buckley (Harvard University) for providing the SV2 antibody, Dr. G. Miesenböck (Yale University) for the pGEX-2T plasmid containing EP, Dr. N. Schecter (SUNY) for the pCS2+ vector, A. Javaherian for assistance with subcloning techniques, Dr. E. Ruthazer for assistance with image analysis macros, Kim Bronson for excellent technical assistance, T. Howard and S. Hearn of the Cold Spring Harbor Microscopy Facility for electron microscopy tissue processing, Dr. K. Svoboda, P. O’Brien, B. Burbach, and Dr. E. Ruthazer for 2-photon microscopy setup, and members of the Cline lab, Dr. Pietro de Camilli, Dr. B. Sabatini, and Dr. Jacek Skowronski for helpful comments on the manuscript.

\section{REFERENCES}

Antonov I, Chang S, Zakharenko S, Popov SV. 1999. Distribution of neurotransmitter secretion in growing axons. Neuroscience 90:975-984.

Ashby MC, De La Rue SA, Ralph GS, Uney J, Collingridge GL, Henley JM. 2004. Removal of AMPA receptors (AMPARs) from synapses is preceded by transient endocytosis of extrasynaptic AMPARs. J Neurosci 24:51725176.

Atluri PP, Ryan TA. 2006. The kinetics of synaptic vesicle reacidification at hippocampal nerve terminals. J Neurosci 26:2313-2320.

Baird GS, Zacharias DA, Tsien RY. 2000. Biochemistry, mutagenesis, and oligomerization of DsRed, a red fluorescent protein from coral. Proc Natl Acad Sci USA 97:11984-11989.

Bouschet T, Martin S, Henley JM. 2005. Receptor-activitymodifying proteins are required for forward trafficking of the calcium-sensing receptor to the plasma membrane. J Cell Sci 118:4709-4720.

Bozza T, McGann JP, Mombaerts P, Wachowiak M. 2004. In vivo imaging of neuronal activity by targeted expression of a genetically encoded probe in the mouse. Neuron 42:9-21.

Brown DA, Rose JK. 1992. Sorting of GPI-anchored proteins to glycolipid-enriched membrane subdomains during transport to the apical cell surface. Cell 68:533544.
Cantallops I, Haas K, Cline HT. 2000. Postsynaptic CPG15 promotes synaptic maturation and presynaptic axon arbor elaboration in vivo. Nat Neurosci 3:1004-1011.

Castellani V, Falk J, Rougon G. 2004. Semaphorin3Ainduced receptor endocytosis during axon guidance responses is mediated by L1 CAM. Mol Cell Neurosci 26:89-100.

Chatterjee S, Mayor S. 2001. The GPI-anchor and protein sorting. Cell Mol Life Sci 58:1969-1987.

Cochilla AJ, Angleson JK, Betz WJ. 1999. Monitoring secretory membrane with FM1-43 fluorescence. Annu Rev Neurosci 22:1-10.

Corriveau RA, Shatz CJ, Nedivi E. 1999. Dynamic regulation of cpg15 during activity-dependent synaptic development in the mammalian visual system. J Neurosci 19:7999-8008.

Dai Z, Peng HB. 1996. Dynamics of synaptic vesicles in cultured spinal cord neurons in relationship to synaptogenesis. Mol Cell Neurosci 7:443-452.

Di Giovanni S, Faden AI, Yakovlev A, Duke-Cohan JS, Finn T, Thouin M, Knoblach S, et al. 2005. Neuronal plasticity after spinal cord injury: Identification of a gene cluster driving neurite outgrowth. FASEB J 19:153-154.

Faivre-Sarrailh C, Rougon G. 1993. Are the glypiated adhesion molecules preferentially targeted to the axonal compartment? Mol Neurobiol 7:49-60.

Faivre-Sarrailh C, Rougon G. 1997. Axonal molecules of the immunoglobulin superfamily bearing a GPI anchor: Their role in controlling neurite outgrowth. Mol Cell Neurosci 9:109-115.

Fernandez-Alfonso T, Ryan TA. 2004. The kinetics of synaptic vesicle pool depletion at CNS synaptic terminals. Neuron 41:943-953.

Field M. 1993. Glycolipid-anchoring of cell surface proteins. In: Schlesinger MJ, editor. Lipid Modifications of Proteins. Boca Raton: CRC Press. pp 83-134.

Fivaz M, Vilbois F, Thurnheer S, Pasquali C, Abrami L, Bickel PE, Parton RG, et al. 2002. Differential sorting and fate of endocytosed GPI-anchored proteins. EMBO J 21:3989-4000.

Foa L, Rajan I, Haas K, Wu GY, Brakeman P, Worley P, Cline H. 2001. The scaffold protein, Homer1b/c, regulates axon pathfinding in the central nervous system in vivo. Nat Neurosci 4:499-506.

Fujino T, Lee WC, Nedivi E. 2003. Regulation of cpg15 by signaling pathways that mediate synaptic plasticity. Mol Cell Neurosci 24:538-554.

Gao WQ, Shinsky N, Armanini MP, Moran P, Zheng JL, Mendoza-Ramirez JL, Phillips HS, et al. 1998. Regulation of hippocampal synaptic plasticity by the tyrosine kinase receptor, REK7/EphA5, and its ligand, AL-1/Ephrin-A5. Mol Cell Neurosci 11:247-259.

Granseth B, Odermatt B, Royle SJ, Lagnado L. 2006. Clathrin-mediated endocytosis is the dominant mechanism of vesicle retrieval at hippocampal synapses. Neuron 51:773-786.

Harel R, Futerman AH. 1996. A newly-synthesized GPIanchored protein, TAG-1/axonin-1, is inserted into axonal membranes along the entire length of the axon and 
not exclusively at the growth cone. Brain Res 712:345348 .

Harwell C, Burbach B, Svoboda K, Nedivi E. 2005. Regulation of cpg 15 expression during single whisker experience in the barrel cortex of adult mice. J Neurobiol 65:85-96.

Holt CE, Garlick N, Cornel E. 1990. Lipofection of cDNAs in the embryonic vertebrate central nervous system. Neuron 4:203-214.

Hu B, Nikolakopoulou AM, Cohen-Cory S. 2005. BDNF stabilizes synapses and maintains the structural complexity of optic axons in vivo. Development 132:4285-4298.

Ikezawa H, Taguchi R. 1981. Phosphatidylinositol-specific phospholipase C from Bacillus cereus and Bacillus thuringiensis. In: Methods in Enzymology. USA: Elsevier. pp 731-750.

Jacob TC, Bogdanov YD, Magnus C, Saliba RS, Kittler JT, Haydon PG, Moss SJ. 2005. Gephyrin regulates the cell surface dynamics of synaptic GABAA receptors. J Neurosci 25:10469-10478.

Javaherian A, Cline HT. 2005. Coordinated motor neuron axon growth and neuromuscular synaptogenesis are promoted by CPG15 in vivo. Neuron 45:505-512.

Javaherian A, Nedivi E, Cline HT. 1998. Developmental regulation of dendritic growth rate in vivo by CPG15. Soc Neurosci Abstr 24:60.

Kennedy MJ, Ehlers MD. 2006. Organelles and trafficking machinery for postsynaptic plasticity. Annu Rev Neurosci 29:325-362.

Kneen M, Farinas J, Li Y, Verkman AS. 1998. Green fluorescent protein as a noninvasive intracellular $\mathrm{pH}$ indicator. Biophys J 74:1591-1599.

Knoll B, Drescher U. 2002. Ephrin-As as receptors in topographic projections. Trends Neurosci 25:145-149.

Kondoh G, Gao XH, Nakano Y, Koike H, Yamada S, Okabe M, Takeda J. 1999. Tissue-inherent fate of GPI revealed by GPI-anchored GFP transgenesis. FEBS Lett 458:299-303.

Le Jan S, Le Meur N, Cazes A, Philippe J, Le Cunff M, Leger J, Corvol P, et al. 2006. Characterization of the expression of the hypoxia-induced genes neuritin, TXNIP and IGFBP3 in cancer. FEBS Lett 580:33953400.

Lee KH, Ryu CJ, Hong HJ, Kim J, Lee EH. 2005. CDNA microarray analysis of nerve growth factor-regulated gene expression profile in rat PC12 cells. Neurochem Res 30:533-540.

Lee WC, Nedivi E. 2002. Extended plasticity of visual cortex in dark-reared animals may result from prolonged expression of cpg15-like genes. J Neurosci 22:18071815.

Li Z, Burrone J, Tyler WJ, Hartman KN, Albeanu DF, Murthy VN. 2005. Synaptic vesicle recycling studied in transgenic mice expressing synaptopHluorin. Proc Natl Acad Sci USA 102:6131-6136.

Lin RC, Scheller RH. 2000. Mechanisms of synaptic vesicle exocytosis. Annu Rev Cell Dev Biol 16:19-49.

Lisanti MP, Caras IW, Gilbert T, Hanzel D, RodriguezBoulan E. 1990. Vectorial apical delivery and slow endocytosis of a glycolipid-anchored fusion protein in trans- fected MDCK cells. Proc Natl Acad Sci USA 87:74197423.

Llopis J, McCaffery JM, Miyawaki A, Farquhar MG, Tsien RY. 1998. Measurement of cytosolic, mitochondrial, and Golgi $\mathrm{pH}$ in single living cells with green fluorescent proteins. Proc Natl Acad Sci USA 95:6803-6808.

Long KE, Asou H, Snider MD, Lemmon V. 2001. The role of endocytosis in regulating L1-mediated adhesion. J Biol Chem 276:1285-1290.

Low MG. 1989. The glycosyl-phosphatidylinositol anchor of membrane proteins. Biochim Biophys Acta 988:427454.

Maletic-Savatic M, Malinow R, Svoboda K. 1999. Rapid dendritic morphogenesis in CA1 hippocampal dendrites induced by synaptic activity. Science 283:1923-1927.

Marron TU, Guerini V, Rusmini P, Sau D, Brevini TA, Martini L, Poletti A. 2005. Androgen-induced neurite outgrowth is mediated by neuritin in motor neurones. J Neurochem 92:10-20.

Matteoli M, Takei K, Perin MS, Sudhof TC, De Camilli P. 1992. Exo-endocytotic recycling of synaptic vesicles in developing processes of cultured hippocampal neurons. J Cell Biol 117:849-861.

Maxfield FR, McGraw TE. 2004. Endocytic recycling. Nat Rev Mol Cell Biol 5:121-132.

Merrifield CJ, Perrais D, Zenisek D. 2005. Coupling between clathrin-coated-pit invagination, cortactin recruitment, and membrane scission observed in live cells. Cell 121:593-606.

Meyer T, Oancea E. 2000. Studies of signal transduction events using chimeras to green fluorescent protein. Methods Enzymol 327:500-513.

Miesenböck G, De Angelis DA, Rothman JE. 1998. Visualizing secretion and synaptic transmission with $\mathrm{pH}$-sensitive green fluorescent proteins. Nature 394:192-195.

Miesenbock G, Rothman JE. 1997. Patterns of synaptic activity in neural networks recorded by light emission from synaptolucins. Proc Natl Acad Sci USA 94:34023407.

Muñiz M, Riezman H. 2000. Intracellular transport of GPIanchored proteins. EMBO J 19:10-15.

Murai KK, Misner D, Ranscht B. 2002. Contactin supports synaptic plasticity associated with hippocampal longterm depression but not potentiation. Curr Biol 12:181190.

Naeve GS, Ramakrishnan M, Kramer R, Hevroni D, Citri Y, Theill LE. 1997. Neuritin: A gene induced by neural activity and neurotrophins that promotes neuritogenesis. Proc Natl Acad Sci USA 94:2648-2653.

Nedivi E, Fieldust S, Theill LE, Hevron D. 1996. A set of genes expressed in response to light in the adult cerebral cortex and regulated during development. Proc Natl Acad Sci USA 93:2048-2053.

Nedivi E, Javaherian A, Cantallops I, Cline HT. 2001. Developmental regulation of CPG15 expression in Xenopus. J Comp Neurol 435:464-473.

Nedivi E, Wu GY, Cline HT. 1998. Promotion of dendritic growth by CPG15, an activity-induced signaling molecule. Science 281:1863-1866.

Developmental Neurobiology 
Nichols BJ, Kenworthy AK, Polishchuk RS, Lodge R, Roberts TH, Hirschberg K, Phair RD, et al. 2001. Rapid cycling of lipid raft markers between the cell surface and Golgi complex. J Cell Biol 153:529-541.

Ohara-Imaizumi M, Nakamichi Y, Tanaka T, Katsuta H, Ishida H, Nagamatsu S. 2002. Monitoring of exocytosis and endocytosis of insulin secretory granules in the pancreatic $\beta$-cell line MIN6 using $\mathrm{pH}$-sensitive green fluorescent protein (pHluorin) and confocal laser microscopy. Biochem J 363:73-80.

Overly CC, Hollenbeck PJ. 1996. Dynamic organization of endocytic pathways in axons of cultured sympathetic neurons. J Neurosci 16:6056-6064.

Pahnke J, Mix E, Knoblich R, Muller J, Zschiesche M, Schubert B, Koczan D, et al. 2004. Overexpression of glial cell line-derived neurotrophic factor induces genes regulating migration and differentiation of neuronal progenitor cells. Exp Cell Res 297:484-494.

Park M, Salgado JM, Ostroff L, Helton TD, Robinson CG, Harris KM, Ehlers MD. 2006. Plasticity-induced growth of dendritic spines by exocytic trafficking from recycling endosomes. Neuron 52:817-830.

Paroutis P, Touret N, Grinstein S. 2004. The pH of the secretory pathway: Measurement, determinants, and regulation. Physiology (Bethesda) 19:207-215.

Pierre K, Dupouy B, Allard M, Poulain DA, Theodosis DT. 2001. Mobilization of the cell adhesion glycoprotein F3/ contactin to axonal surfaces is activity dependent. Eur $\mathrm{J}$ Neurosci 14:645-656.

Piper M, Anderson R, Dwivedy A, Weinl C, van Horck F, Leung KM, Cogill E, et al. 2006. Signaling mechanisms underlying Slit2-induced collapse of Xenopus retinal growth cones. Neuron 49:215-228.

Piper M, Salih S, Weinl C, Holt CE, Harris WA. 2005. Endocytosis-dependent desensitization and protein synthesis-dependent resensitization in retinal growth cone adaptation. Nat Neurosci 8:179-186.

Polak JM, Varndell IM, editors. 1984. Immunolabelling for Electron Microscopy. Amsterdam: Elsevier.

Putz U, Harwell C, Nedivi E. 2005. Soluble CPG15 expressed during early development rescues cortical progenitors from apoptosis. Nat Neurosci 8:322-331.

Ruthazer E, Cline HT. 2002. Multiphoton imaging of neurons in living tissue: Acquisition and analysis of time-lapse morphological data. Real-Time Imaging 8:175-188.

Rybicka KK, Udin SB. 1994. Ultrastructure and GABA immunoreactivity in layers 8 and 9 of the optic tectum of Xenopus laevis. Eur J Neurosci 6:1567-1582.
Sankaranarayanan S, Ryan TA. 2000. Real-time measurements of vesicle-SNARE recycling in synapses of the central nervous system. Nat Cell Biol 2:197-204.

Shang Y, Claridge-Chang A, Sjulson L, Pypaert M, Miesenbock G. 2007. Excitatory local circuits and their implications for olfactory processing in the fly antennal lobe. Cell 128:601-612.

Siegel MS, Isacoff EY. 2000. Green fluorescent proteinbased sensors for detecting signal transduction and monitoring ion channel function. Methods Enzymol 327:249259.

Simons K, Toomre D. 2000. Lipid rafts and signal transduction. Nat Rev Mol Cell Biol 1:31-39.

Tetzlaff JE, Huppenbauer CB, Tanzer L, Alexander TD, Jones KJ. 2006. Motoneuron injury and repair: New perspectives on gonadal steroids as neurotherapeutics. J Mol Neurosci 28:53-64.

Walsh FS, Doherty P. 1991. Glycosylphosphatidylinositol anchored recognition molecules that function in axonal fasciculation, growth and guidance in the nervous system. Cell Biol Int Rep 15:1151-1166.

Walsh FS, Doherty P. 1997. Neural cell adhesion molecules of the immunoglobulin superfamily: Role in axon growth and guidance. Annu Rev Cell Dev Biol 13:425456.

Wang GX, Poo MM. 2005. Requirement of TRPC channels in netrin-1-induced chemotropic turning of nerve growth cones. Nature 434:898-904.

Wang YX, Wenthold RJ, Ottersen OP, Petralia RS. 1998. Endbulb synapses in the anteroventral cochlear nucleus express a specific subset of AMPA-type glutamate receptor subunits. J Neurosci 18:1148-1160.

Wibrand K, Messaoudi E, Havik B, Steenslid V, Lovlie R, Steen VM, Bramham CR. 2006. Identification of genes co-upregulated with Arc during BDNF-induced longterm potentiation in adult rat dentate gyrus in vivo. Eur $\mathbf{J}$ Neurosci 23:1501-1511.

Yamashiro DJ, Maxfield FR. 1984. Acidification of endocytic compartments and the intracellular pathways of ligands and receptors. J Cell Biochem 26:231-246.

Yen L, Sibley JT, Constantine-Paton M. 1995. Analysis of synaptic distribution within single retinal axonal arbors after chronic NMDA treatment. J Neurosci 15:47124725.

Zakharenko S, Chang S, O’Donoghue M, Popov SV. 1999. Neurotransmitter secretion along growing nerve processes: Comparison with synaptic vesicle exocytosis. J Cell Biol 144:507-518. 